University of Nebraska - Lincoln

DigitalCommons@University of Nebraska - Lincoln

2003

\title{
Geography of Religion and Belief Systems
}

\author{
Robert H. Stoddard \\ University of Nebraska-Lincoln, rstoddard1@unl.edu \\ Carolyn V. Prorok \\ Slippery Rock University of Pennsylvania, carolyn.prorok@sru.edu
}

Follow this and additional works at: https://digitalcommons.unl.edu/geographyfacpub

Part of the Geography Commons

Stoddard, Robert H. and Prorok, Carolyn V., "Geography of Religion and Belief Systems" (2003). Geography Faculty Publications. 35.

https://digitalcommons.unl.edu/geographyfacpub/35

This Article is brought to you for free and open access by the Geography Program (SNR) at DigitalCommons@University of Nebraska - Lincoln. It has been accepted for inclusion in Geography Faculty Publications by an authorized administrator of DigitalCommons@University of Nebraska - Lincoln. 


\title{
Geography of Religion and Belief Systems
}

\author{
Robert H. Stoddard and Carolyn V. Prorok
}

Spatial and environmental dimensions of religious behavior, artefacts, and attitudes are grist for the geographer's intellectual mill because spiritually motivated convictions and actions play an important role in human affairs. It is not surprising, therefore, that the geography of religion and belief systems is an important, emerging field of study.

We commence this chapter with a definition of the field, particularly as it entails distinctions that arise out of the highly personal nature that religious belief is accorded in the academy and society at large. A limited review and summary of trends in the field over the past decade follows, building on Kong's (1990) and Sopher's (1967, 1981) overviews. Although North American geographers are emphasized here, research in the geography of religion is thoroughly entwined in terms of scholars' national origin, university training, and research perspectives, thus making distinctions in nationality difficult. Moreover, geographers who do not consider themselves to be geographers of religion and numerous nongeographers also make significant contributions to this field because their work clearly incorporates both religious and geographic components in their analysis and subject matter.

We note that traditional empirical studies largely dominate the work published in the last decade. Nevertheless, humanistic research (Weightman 1996; Cooper 1997a; Prorok 1997; Osterrieth 1997), and the application of contemporary critical theory (Fielder 1995; Kong 1993a, b; Prorok 2000) in this field is gaining ground, particularly via recent dissertations and presentations at AAG meetings. Additional comments about future challenges and opportunities conclude the chapter.

\section{The Focus of Study}

No universally accepted definition of religion exists, as illustrated by the hundreds already published and others continually being introduced (see e.g. a separate bibliographical cate- gory devoted annually to this definitional task in Social Compass: International Review of Sociology of Religion). Another indication that the term "religion" lacks a single, precise definition is the continual struggle, expressed repeatedly within the American judicial system, with questions about what are truly "religious" activities. Definitions vary in their emphasis on three contrasting perspectives: (1) a transcendental divinity; (2) an immanent spirituality that permeates all of life; and (3) an ethical philosophy. Even though a formal definition of religion is seldom stated by geographers, it appears from their writings that most accept a definition close to the following: Religion is a system of beliefs and practices that attempts to order life in terms of culturally perceived ultimate priorities.

When the field of study is titled "geography of religion and belief systems," the commonality of studies becomes even less precise. In general, the transitional zone between what is regarded as religious and what is accepted as non-religious includes those beliefs and activities considered spiritual and containing a sense of "oughtness" or obligation. When persons believe they conscientiously "should" behave in a certain way (rather than just because "traditionally everyone does it this way") or they have faith that certain group action carries a synergism greater than one's own power (Bartkowski and Swearingen 1997), their actions fall within the realm regarded as "other religious-like belief systems." This more inclusive term also encompasses "civil religion," which refers to beliefs and practices expressed through informal mass adherence, often containing a strong nationalist fervor. Even though beliefs may not necessarily be organized systematically, the popular acceptance of national mythology, revered symbols, and hallowed places closely resemble characteristics of formal religions. As with other belief systems containing culturally perceived ultimate priorities, the motives for honoring patriotic icons, preserving hallowed grounds, and visiting sanctified sites originate from a sense of "shouldness." 


\section{Methodological Issues}

A fundamental methodological issue concerns the epistemological stance of persons seeking to explain religious phenomena. Two views adopted here to simplify the discussion are those of Believers and Observers.

Believers are those who hold certain beliefs on faith. They often believe specific conditions exist because of transcendental forces, such as divine will. They affirm that the divine is manifested in sacred texts, holy places, and/or absolute ethics. From the perspective of Believers, certain research questions posed by outside observers are irrelevant-and irreverent-because such queries indicate doubt about what is already "known." The category of Believers also includes persons who, while not always believing in divine intervention, declare that certain objects (say, a national flag) and places (illustrated by the site where a national hero was martyred) become sacred. For those holding nontheistic philosophical positions (for instance, the sanctity of Mother Earth), and even for those who recognize human elements in the creation of sacred spaces (such as battlefield cemeteries), beliefs about certain behavior, nevertheless, exist as fundamental assumptions. Although non-theistic Believers may be receptive to studies about how certain sacred places function within the society, from their perspective the element of sanctity per se should not - and cannot-be challenged.

"Observers" refers to non-Believers, who may hold varying positions about Believers' convictions, ranging from empathy to hostility. Positions of geographic Observers, seeking to understand and explain the spatial and ecological aspects of religion and belief systems, vary. For geographers who are personally skeptics, secularists, or agnostics, the stance of Observer is that of an outsider. In contrast, for geographers studying a particular religion while personally being a Believer of that same religion, there exists a tension between trying to understand relationships and conditions objectively while also unquestionably believing some were created by the divine. For other geographers who are Believers but who seek to observe a religion or belief system different from their own, the role of outside Observer is similar though not equivalent to that of a relatively dispassionate inquirer.

Some scholars of religion declare that Observers cannot fully comprehend and thus truly "explain" a religion of which they are not a believ- ing member because an Observer's own values and experiences distort a true understanding of the motives affecting the behavior of Believers. However, the degree to which this outside-ness affects scholarship epistemologically is probably not different from other geographic studies about which researchers may hold perspectives ranging from empathy to hostility.

The contrasting views of Observers and Believers are indicated by the customary differentiation between the geography of religion and religious geography. The latter pertains to information about the geographic (that is, spatial and ecological) characteristics of religious phenomena written from the perspective of a Believer in those same phenomena (Isaac 1965). Writings about sacred geometry and/or the locations of a divinity's manifestation on Earth (Singh 1991), environmental events recorded in sacred texts (Mather and Mather 1997), or advocacy for religious sentiment in urban development (Pacione 1999) are a few examples. Although such materials may be examined by geographers of religion for the purpose of gaining insight into the motivations of Believers, they are not considered a part of the academic field being discussed here. The debate concerning Believer versus Observer epistemological positions in the field is an important one given the desire of some academic geographers not to restrict study to a particular faith system or sacred text nor to become disseminators of sectarian viewpoints (Raivo 1997; Dawson 2000).

Likewise, recent writings labeled as "spiritual geography" are not considered here as a part of the geography of religion. Although they often deal with religious feelings about the natural environment at particular places, each is representative of unique, personal experiences written from the viewpoint of a Believer (Norris 1993; Henderson 1993; Pulido 1998). In contrast, geographers of religion have focused primarily on religious behavior and artefacts of groups of people.

Another methodological issue in this field concerns the directional relationships between religion and other phenomena. One approach commences with observations about the spatial characteristics of religion and then seeks to explain those locational and ecological aspects in terms of relationships with other phenomena, which is similar to the way studies in economic, political, and physical geography are normally designed. The alternative approach begins with religious beliefs and attempts to demonstrate their 
impact or effect on the spatial and ecological characteristics of other phenomena. Although most branches of geography are seldom defined in this manner, the geography of religion has a long history of such "impact" studies.

To a certain extent, this discussion about the two approaches exaggerates a distinction that may be insignificant because relationships among phenomena are seldom understood well enough to specify which ones have the greatest influence on a complex of others. Since reciprocal relationships permeate most human relationships, it is difficult to sort out the degree that religious beliefs affect, and are affected by, numerous economic, political, social, and environmental phenomena.

\section{Clusters of Emphasis}

For the purposes of organization and to identify trends, we have grouped the body of literature into three clusters: studies on the impact of religion, distributional studies, and geographic studies of religious phenomena.

\section{Studies on the Impact of Religion}

Religious beliefs and behavior are so significantly and thoroughly intertwined with the lifeways of numerous communities around the world that geographers have often focused upon the impact of religion on other human endeavors. The basic message is that religious beliefs and practices influence natural environments as well as the locations and spatial characteristics of specified economic, political, cultural, or physical phenomena. The degree to which geographical characteristics of these other features are affected by religion is seldom measured, but the extent of the impact is deemed significant. Examples of such studies include the influence of religion on the distribution of urban neighborhoods and agricultural settlements (Katz 1991), the characteristics and political behavior of a region (Webster 1997), the distribution of specific plants and their uses (Voeks 1990), and settlement patterns (Abruzzi 1993). Geographers of religion have a long tradition of studying the role of religious belief and behavior on the formation of cultural landscapes. Such studies include the plurality of religions evident in urban landscapes (Weightman 1993; Numrich 1997; Ley and Martin 1993), settlement mythology (Kuhlken 1997), symbolic landscapes (Mal- ville 1998), and urban design (Sinha 1998).

A recent trend, by geographers and other scholars, is an increase in studies on the role of religion in forming beliefs and attitudes about the environment. Typical are questions about the relationship between theology and conservation (Braden 1999), varying environmental positions of Christian groups (Curry-Roper 1990), sacred interpretations of ecophysiology by modern scientists (Cooper 1997a), and the merits of environmental activism (Tharan 1997).

\section{Distributional Studies}

Primary locational data on religious affiliations are difficult to obtain, especially in the United States where recent governmental censuses have not collected such information. This means that geographers studying religious affiliation may necessarily devote more attention to the acquisition of data than in many other fields of geography. One publication providing valuable distributional data originates from the Glenmary Research Center (Bradley et al. 1992); another, which incorporates data from numerous sources, is the atlas of religious change in America (Newman and Halvorson 2000). Of particular importance is the monumental revision of the atlas of religion in America (Gaustad and Barlow 2000), which reflects contemporary trends in cartographic technology. In addition, many atlases and encyclopedia collect and present a wide variety of religious phenomena at the national and international levels (e.g. O'Brien et al. 1993; Brockman 1997; Barrett et al. 2000; Smart 1999).

Other distributional publications are those combining locational data with suggested relationships but with limited analysis. Such is exemplified by the distribution of churches in a US county (Andrews 1990), prevalence of almshouses in Jerusalem (Shilong 1993), regional expression of poverty programs supported by religious dioceses (Pacione 1991), sociological characteristics of religion in different regions of the United States (McGuire 1991), and the distribution of Canadian Mormons in North America (Louder 1993). Also assigned to this cluster are studies in which religious affiliation is a critical element in the identification of a population, even though it is often difficult to apportion the role of religion within the mingled cultural complex of a particular group (Sheskin 1993; Morin and Guelke 1998; Hardwick 1991, 1993a, b; Tharan 1997; Emmett 1995). 


\section{Geographic Studies of Religious Phenomena}

This cluster encompasses research designed to understand and explain the spatial variations in those populations, features, and activities regarded as religious. Several studies have examined factors associated with membership in religious organizations (Katz and Lehr 1991; Krindatch 1996), while other geographic questions have dealt with religious buildings and observable features (Diamond 1997; Prorok and Kimber 1997; Prorok and Hemmasi 1993; Bhardwaj and Rao 1998; Prorok 1998, 1991). Although some institutional structures (such as schools, soup kitchens, and cemeteries) associated with religious organizations may be studied geographically, they are excluded from this cluster if they are not treated primarily as phenomena of religion. A study that illustrates well a geographic analysis of religion is by Stump (2000), who examines the commonalities and political implications of fundamentalist movements in several world religions.

A topic that recently has attracted considerable academic attention concerns sacred places, which are those Earth locations deemed by Believers to be holy territory. Because the locations of most sanctified sites are identified by observable religious features and rituals, they can be analyzed geographically. In many cases, certain rituals occur only at a particular sacred site, which creates a tremendous motivation for journeys by Believers to that unique place. Thus, even though the ritualistic movements within the confines of the holy site occur at a scale not often studied by geographers, travel to these religious nodes (i.e. pilgrimages) create considerable geographic interest.

Another characteristic of a sacred place is the manifestation of power required to control the land and its use. Because a sacred place consists of an actual areal plot (which is often clearly demarcated), it incorporates all the properties associated with territorial control of land. Frequently sacred sites are contested with accompanying issues of ownership, maintenance, and access to the site, as well as the very identification of its status as "sacred." Disputes over territory may involve more than just the religious attributes of participants because the stakes are magnified when group members believe- or are emotionally convinced - that certain territory belongs to them. That is, they base their right to specific real estate not only from a long his- tory of attachment to the area, or the strength of internationally accepted documents of sovereignty, but also from a belief that the land has been assigned to them by a divine power (Benvenisti 2000; Friedland and Hecht 1991; Emmett 1996, 1997).

Other conflicts over ownership, maintenance, and access to land that is sacred to indigenous people may not always generate as much publicity as regional wars, but they involve some of the same fundamental issues. The desecration of Native Americans' sacred sites often occurs from intrusion by roads, mines (Jett 1992), and tourists (Price 1994). Similar conflicts occur in other regions where economic interests clash with the religious geography of indigenous groups (Fielder 1995). Controversies may also erupt over the use of land where sanctified structures have existed for long periods of time but now occupy sites coveted by economic developers or are deleteriously affected by recent development (Hobbs 1992; Kong 1993b; Tobin 1998).

This trend toward a heightened interest in sacred places is evidenced by the variety of studies. The general topic has been publicized by academicians (Park 1994; Cooper 1997b) and in popular books (Harpur 1994; Brockman 1997). Researchers have focused on the emotional experiences of Believers (Geffen 1998; Dobbs 1997; Forbes-Boyte 1998), on the concept of sacred places by specific religious groups (Bascom 1998), and on cemeteries as sanctified areas (Nakagawa 1990; Yeoh and Hui 1995; Teather 1999). Others have studied the process through which places become sacred (Nolan and Nolan 1997; Prorok 1997; Bhardwaj 1990; Berg 1998; Singh 1997), and on the geometric patterns of a religious cosmology along with the sacred sites that define it (Gutschow 1994; Singh 1994; Singh and Malville 1995; van Spengen 1998; Buffetrelle 1998; Kuhlken 1997; Grapard 1998; Malville 1998). Similarly, scholars have attempted to understand spatial behavior associated with places revered as part of civil religion (Zelinsky 1990; Sellers and Walters 1993; Foote 1997; Sherrill 1995; Azaryahu 1996; Ben-Israel 1998). In the United States, the Gettysburg Battlefield, the Vietnam War Memorial, Arlington National Cemetery, the Arizona in Pearl Harbor, and Graceland all illustrate sites sanctified primarily by the multitude of pilgrims, who possess a strong desire to visit and to experience a sense of spirituality there. 
Because both the topics of sacred places and religious movement are inherently geographic, the study of pilgrimage constitutes an important emphasis by geographers of religion. It is not surprising, given the large amount of research on pilgrimage, that the relevant literature covers a variety of aspects. General essays about pilgrimage include a summary of their distinctive geographic characteristics (Stoddard and Morinis 1997a), a comprehensive review of and commentary on contemporary pilgrimage studies by geographers (Bhardwaj 1997), and a discussion about the differentiation between journeys motivated by religion versus tourism (Smith 1992). Pilgrimages have been classified according to the type of attraction (Nolan and Nolan 1992) and by length of journey, route configurations, and frequency of events (Stoddard 1997).

A substantial number of studies illuminate pilgrimage traditions by attempting to understand relationships among pilgrims' backgrounds, motivations for religious undertakings, size of nodal fields, and distributions of sacred sites by concentrating on a single religious tradition in one region (Din and Hadi 1997; Nolan and Nolan 1997; Rinschede 1990; Jackowski 1990; Jackowski and Smith 1992; Jackson et al. 1990; Hudman and Jackson 1992; Bhardwaj 1990; Cameron 1990; McDonald 1995; Zelinsky 1990). Other studies emphasize the complex of interrelationships occurring at a single pilgrimage site, such as in Mecca (Rowley 1997); at the basilica for Our Lady of Consolation in Carey, Ohio (Faiers and Prorok 1990); the shrine in Belleville, Illinois (Giuriati et al. 1990); the sangam at Prayag, India (Caplan 1997); the Himalayan site at Muktinath (Kaschewsky 1994); the Sikh shrine at Patna, India (Karan 1997); Lourdes (Giuriati and Lanzi 1994); Graceland in Memphis, Tennessee (Davidson et al. 1990), and the set of Buddhist temples located around Shikoku island (Shimazuki 1997), to name a few. Methodological approaches vary, with one group searching for general relationships, such as locational associations with major world pilgrimage sites (Stoddard 1994), the effects of scale on observed relationships (Rinschede 1997), and the empirical validity of the core-versus-periphery hypothesis (Sopher 1997; Cohen 1992). Others struggle with understanding the tensions people experience between travel and attachment to home (Osterreith 1997) and contemplate the pilgrimage experience in and of itself (Wagner 1997). An interesting pilgrimage variant is to visit a wan- dering ascetic rather than a fixed earth location (McCormick 1997).

Understanding religious pilgrimages (which involves more complexity than provided, for example, by economic models) requires examination from many disciplinary efforts. Thus, geographers of pilgrimage have welcomed insights by scholars in other disciplines (especially anthropology, sociology, and religious studies), who, unfortunately, have not always realized (or seem to consider) geographers as contributors or geographic literature as relevant (Crumrine and Morinis 1991; Naquin and Yu 1992; Reader and Walters 1993; Carmichael et al. 1994; Chidester and Linenthal 1995; Kedar and Werblowsky 1998).

\section{Conclusion}

Even though some forms of religious activity may have declined in certain regions of the world during the last century, religion continues to be a critical component of many human events. Religion is often a vital element in understanding, for example, the ethno-regional conflicts over the possession and control of specific territory, the gathering of millions of worshipers who journey to particular places, the patterns of electoral results in various democracies, and local disputes about the role of governmental regulations of public institutions and land use. Consequently, as long as geographers seek to explain the spatial behavior of humans, there will exist the need to analyze religion and similar belief systems geographically.

As an organized field of study, the geography of religion and belief systems (GORABS) is relatively young but, as judged by Zelinksy (1994: 126), showing "every sign of viability and growth". While geographic questions have been asked about religious behavior and artefacts for a long time, the first formal gathering of interested scholars did not occur until the 1965 annual meeting of the AAG (Stoddard 1990). The rise of radical and humanistic geographies in the 1960s and 1970s (Peet 1998) may have played a role in the formal emergence of this specialty inasmuch as "touchy-feely" geography became more and more acceptable in general. Even so, many geographers of religion at the time were not really interested in joining the touchy-feely side of the academy. Instead, they struggled to gain respect for research with a strong empirical basis, in part to show that peoples' religious behavior 
deserves the same attention and respect as their social, cultural, political, and economic behavior. Dedication to studying religion as Observers differentiated these geographers from those who might promote a particular sectarian viewpoint and thus undergirded their strong emphasis on empirical work within the field.

Calls have been made to supplement this empirical emphasis with more theoretical approaches (Sopher 1981; Levine 1986; Cooper 1992; Wilson 1993) although a recent article by Kong (2001) indicates that this is already beginning to occur. And, while a few geographers of religion have successfully combined empirical and contemporary critical ideas in their work (Stump 2000), there is still the challenge of devising theoretical frameworks applicable to people's spatial behavior that is religiously motivated (and thus contrasting with economic models). Forays into theoretical approaches among contemporary geographers of religion have relied mainly on critical theories (e.g. feminist, post-colonial, and postmodern) and philosophies (e.g. phenomenology and existentialist) that did not originate in geographic thought but which have been adopted by geographers in a number of specializations (Peet 1998). Other credible contributions to theoretical frameworks made by nongeographers (Malville 1999; Tweed 1997; Brenneman and Brenneman 1995) serve as future challenges to geographers of religion.

Because religion permeates many aspects of human behavior we predict academic attempts to understanding its spatial and environmental manifestations will continue to be vigorously pursued, particularly in the various clusters of topics as discussed above. As with other fields of geography, more sophisticated methods of observation and analysis undoubtedly will be employed in the future. Other scholars, striving to gain greater insight into the complex interrelationships among religious and other human attributes, motivations, and behavioral patterns will conduct further studies using critical theories and humanistic perspectives. And the call for creating original, relevant theories of spatio-religious behavior will increasingly challenge scholars. These endeavors will require sensitively applied skills in observation and analysis as well as true empathy while, at the same time, carefully avoiding the advocation of a particular religious doctrine. We are convinced that these goals can be achieved and geographers of religion will continue to organize and disseminate substantial new knowledge in the twenty-first century.

\section{References}

Abruzzi, W.S. (1993). Dam That River!: Ecology and Mormon Settlement in the Little Colorado River Basin. Lanham, Md.: University Press of America.

Andrews, A. (1990). "Religious Geography of Union County, Georgia." Journal of Cultural Geography, 10: 1-19.

Azaryahu, M. (1996). “The Spontaneous Formation of Memorial Space: The Case of Kikar Rabin, Tel Aviv." Area, 28: 501-513.

Barrett, D.B., G.T. Kurian and T.M. Johnson (2000). World Christian Encyclopedia: A Comparative Survey of Churches and Religions A.D. 30-A.D. 2000. 2nd edition. New York: Oxford University Press.

Bartkowski, J.P., and W.S. Swearingen (1997). “God Meets Gaia in Austin, Texas: A Case Study of Environmentalism as Implicit Religion." Review of Religious Research, 38: 308-324.

Bascom, J. (1998). “The Religious Geography of Evangelical Christians in North America." Pennsylvania Geographer, 36: 148-168.

Ben-Israel, H. (1998). "Hallowed Land in the Theory and Practice of Modern Nationalism," in B.Z. Kedar and R.J.Z. Werblowsky (editors), Sacred Space: Shrine, City, Land. New York: New York University Press, 78-94.

Benvenisti, M. (2000). Sacred Landscape: The Buried History of the Holy Land Since 1948. Berkeley: University of California Press.

Berg, E. (1998). “The Sherpa Pilgrimage to Uomi Tsho in the Context of the Worship of the Protector Deities: Ritual Practices, Local Meanings, and This-Wordly Request." Himalayan Research Bulletin, 18: 19-34.

Bhardwaj, S.M. (1990). "Hindu Deities and Pilgrimages in the United States," in G. Rinschede and S. M. Bhardwaj (editors), Pilgrimage in the United States. Berlin: Dietrich Reimer, 211-228.

Bhardwaj, S.M. (1997). "Geography and Pilgrimage: A Review," in Stoddard and Morinis (1997b: 1-23).

Bhardwaj, S.M., and M.N. Rao (1998). "The Temple as a Symbol of Hindu Identity in America?" Journal of Cultural Geography, 17: 125-143.

Braden, K. (1999). "Description of the Earth in Four Spiritual Maps." Geography of Religions and Belief Systems, 21/1: 1-3.

Bradley, M.B., N.M. Green, D.E. Jones, M. Lynn and L. McNeil (1992). Churches and Church Membership in the United States, 1990. Atlanta: Glenmary Research Center.

Brenneman, W.L., Jr., and M.G. Brenneman (1995). Crossing the Circle at the Holy Wells of Ireland. Charlottesville: University Press of Virginia.

Brockman, N.C. (1997). Encyclopedia of Sacred Places. Santa Barbara: ABC-CLIO.

Buffetrelle, K. (1998). "Reflections on Pilgrimages to Sacred Mountains, Lakes and Caves," in B.Z. Kedar and R.J.Z. Werblowsky (editors), Sacred Space: Shrine, City, Land. New York: New York University Press, 18-34.

Cameron, C. (1990). "Pilgrims and Politics: Sikh Gurdwaras in California," in G. Rinschede and S. M. Bhardwaj (editors), Pilgrimage in the United States. Berlin: Dietrich Reimer Verlag, 193-209. 
Caplan, A. (1997). “The Role of Pilgrimage Priests in Perpetuating Spatial Organization within Hinduism," in Stoddard and Morinis (1997b: 209-233).

Carmichael, D.L., J.L. Hebert, B. Reeves and A. Schanche (editors) (1994). Sacred Sites, Sacred Places. London: Routledge.

Chidester, D., and E.T. Linethal (editors) (1995). American Sacred Space. Bloomington: Indiana University Press.

Cohen, E. (1992). “Pilgrimage Centers: Concentric and Excentric." Annals of Tourism Research, 19: 33-50.

Cooper, A. (1992). "New Directions in the Geography of Religion." Area, 24: 123-129.

Cooper, A. (1997a). "Sacred Interpretations of the Ecophysiology in Tropical Forest Canopies." Pennsylvania Geographer, 35/2: 5-31.

Cooper, A. (1997b). Sacred Mountains: Ancient Wisdom and Modern Meaning. Edinburgh: Floris Books.

Crumrine, N.R., and E.A. Morinis (editors) (1991). Pilgrimage in Latin America. New York: Greenwood Press.

Curry-Roper, J.M. (1990). “Contemporary Christian Eschatologies and Their Relation to Environmental Stewardship." Professional Geographer, 42: 57-69.

Davidson, J.W., A. Hecht and H.A. Whitney (1990). "The Pilgrimage to Graceland," in G. Rinschede and S.M. Bhardwaj (editors), Pilgrimage in the United States. Berlin: Dietrich Reimer, 229-252.

Dawson, A.H. (2000). "Geography, Religion and the State: A Comment on an Article by Michael Pacione." Scottish Geographical Journal, 116: 59-65.

Diamond, E. (1997). "Places of Worship: The Historical Geography of Religion in a Midwestern City, 1930-1960." Pennsylvania Geographer, 35: 45-68.

Din, A.K., and A.S. Hadi (1997). "Muslim Pilgrimage from Malaysia," in Stoddard and Morinis (1997b: 161-182).

Dobbs, G.R. (1997). “Interpreting the Navajo Sacred Geography as a Landscape of Healing." Pennsylvania Geographer, 35: 136-50.

Emmett, C. (1995). Beyond the Basilica: Christians and Muslims in Nazareth; Geography Research Paper, 237. Chicago: Chicago University Press.

Emmett, C. (1996). "The Capital Cities of Jerusalem." The Geographical Review, 86: 233-258.

Emmett, C. (1997). "The Status Quo Solution for Jersusalem." Journal of Palestine Studies, 26: 16-28.

Faiers, G.E., and C.V. Prorok (1990). "Pilgrimage to a 'National' American Shrine: 'Our Lady of Consolation' in Carey, Ohio," in' G. Rinschede and S. M. Bhardwaj (editors), Pilgrimage in the United States. Berlin: Dietrich Reimer, 137-147.

Fielder, J. (1995). "Sacred Sites and the City: Urban Aboriginality Ambivalence and Modernity," in R. Wilson and A. Dirlik (editors), Asia/Pacific as Space of Cultural Production. London: Duke University Press, 101-119.

Foote, K.E. (1997). Shadowed Ground: America's Landscapes of Violence and Tragedy. Austin: University of Texas Press.

Forbes-Boyte, K. (1998). "It is All Sacred: Foothill Konkow Religious Perceptions of Sacred Place." The Pennsylvania Geographer, 36: 5-29.
Friedland, R., and R.D. Hecht (1991). "The Politics of Sacred Space: Jerusalem's Temple Mount/al-Sharif," in Scott and Simpson-Housley (1991: 21-61).

Gaustad, E.S., and P.L. Barlow (2000). New Historical Atlas of Religion in America. New York: Oxford University Press.

Geffen, J.P. (1998). "Landscapes of the Sacred: Avebury as a Case Study." Geography of Religions $\mathcal{E}$ Belief Systems, 20/2: 1, 3-4.

Giuriati, P., P.M.G. Myers and M.E. Donach (1990). "Pilgrims to 'Our Lady of the Snows' Belleville, Illinois in the Marian Year: 1987-1988," in G. Rinschede and S. M. Bhardwaj (editors), Pilgrimage in the United States. Berlin: Dietrich Reimer, 49-192.

Giuriati, P., and G. Lanzi (1994). "Pilgrims to Fatima as Compared to Lourdes and Medjugorje," in S. Bhardwaj, G. Rinschede and A. Sievers (editors), Pilgrimage in the Old and New World. Berlin: Dietrich Reimer, 57-79.

Grapard, A.B. (1998). “Geotyping Sacred Space: The Case of Mount Hiro in Japan," in B.Z. Kedar and R. J.Z. Werblowsky (editors), Sacred Space: Shrine, City, Land. New York: New York University Press, 215-258.

Gutschow, N. (1994). "Varanasi/Benares: The Centre of Hinduism?" Erdkunde, 48: 94-209.

Hardwick, S. (1991). "The Impact of Religion on Ethnic Survival: Russian Old Believers in Alaska." The California Geographer, 31: 19-36.

Hardwick, S. (1993a). "Origin and Diffusion of Russian Baptists and Pentecostals in Russia and Ukraine." Pennsylvania Geographer, 31: 2-13.

Hardwick, S. (1993b). Russian Refuge: Religion, Migration, and Settlement on the North American Pacific Rim. Chicago: University of Chicago Press.

Harpur, J. (1994). Atlas of Sacred Places: Meeting Points of Heaven and Earth. New York: Henry Holt.

Henderson, M.L. (1993). "What Is Spiritual Geography?" Geographic Review, 83: 469-472.

Hobbs, J.J. (1992). “Sacred Space and Touristic Development At Jebel Musa (Mt. Sinai), Egypt." Journal of Cultural Geography, 12: 99-113.

Hudman, L.E., and R.H. Jackson (1992). “Mormon Pilgrimage and Tourism." Annals of Tourism Research, 19: 107-121.

Isaac, E. (1965). "Religious Geography and the Geography of Religion," in Man and the Earth; University of Colorado Studies, Series in Earth Sciences, 3. Boulder: University of Colorado Press, 1-14.

Jackowski, A. (1990). “Development of Pilgrimages in Poland: Geographical-Historical Study," in G. Lallanji and D.P. Dubey (editors), Pilgrimage Studies: Text and Context. Allahabad: Society of Pilgrimage Studies, 241-50.

Jackowski, A., and V.L. Smith (1992). "Polish PilgrimTourists." Annals of Tourism Research, 19: 92-106.

Jackson, R.H., G. Rinschede and J. Knapp (1990). “Pilgrimage in the Mormon Church," in G. Rinschede and S.M. Bhardwaj (editors), Pilgrimage in the United States. Berlin: Dietrich Reimer, 27-61.

Jett, S.C. (1992). "An Introduction to Navajo Sacred Places." Journal of Cultural Geography, 13: 29-39. 
Karan, P.P. (1997). "Patterns of Pilgrimage to the Sikh Shrine of Guru Gobind Singh at Patna," in Stoddard and Morinis (1997b: 257-68).

Kaschewsky, R. (1994). "Muktinath-A Pilgrimage Place in the Himalayas," in S. Bhardwaj et al. (editors), Pilgrimage in the Old and New World. Berlin: Dietrich Reimer, 139-168.

Katz, Y. (1991). "The Jewish Religion and Spatial and Communal Organization: The Implementation of Jewish Religious Law in the Building of Urban Neighborhoods and Jewish Agricultural Settlements in Palestine at the Close of the Nineteenth Century," in Scott and Simpson-Housley (1991: 3-19).

Katz, Y., and J.C. Lehr (1991). "Jewish and Mormon Agricultural Settlement in Western Canada: A Comparative Analysis." The Canadian Geographer, 35: 128-142.

Kedar, B.Z., and R.J.Z. Werblowsky (editors) (1998). Sacred Space: Shrine, City, Land. New York: New York University Press.

Kong, L. (1990). “Geography and Religion: Trends and Prospects." Progess in Human Geography, 14: 355-371.

Kong, L. (1993a). "Ideological Hegemony and the Political Symbolism of Religious Buildings in Singapore." Environment \& Planning D: Society E Space, 11: 23-46.

Kong, L. (1993b). "Negotiating Conceptions of 'Sacred Space': A Case Study of Religious Buildings in Singapore." Transactions of the Institute of British Geographers, 18: 342-358.

Kong, L. (2001). "Mapping 'New' Geographies of Religion: Politics and Poetics in Modernity," Progress in Human Geography, 25/2: 211-233.

Krindatch, A. (1996). Geography of Religions in Russia. Decatur, Ga.: Glenmary Research Center.

Kuhlken, R. (1997). "Sacred Landscapes and Settlement Mythology in the Fiji Islands." Pennsylvania Geographer, 35: 173-202.

Levine, G.J. (1986). “The Geography of Religion.” Transactions, Institute of British Geographers, 11: 428-440.

Ley, D., and R.B. Martin (1993). "Gentrification as Secularization: The Status of Religious Belief in the PostIndustrial City." Social Compass, 40: 217-231.

Louder, D.R. (1993). "Canadian Mormons in their North American Context: A Portrait." Social Compass, 40: 271-290.

McCormick, T. (1997). "The Jaina Ascetic as Manifestation of the Sacred," in Stoddard and Morinis (1997b: 235-56).

McDonald, D. (1995). "Changes Along the Peyote Road." Geography of Religions and Belief Systems, 17/2: 1-4.

McGuire, M.B. (1991). "Religion and Region: Sociological and Historical Perspective." Journal for the Scientific Study of Religion, 30: 544-547.

Malville, J.M. (1998). “The Symbolic Landscape of Vijayanagara." Pennsylvania Geographer, 36: 30-54.

Malville, J.M. (1999). "Complexity and Self-Organization in Pilgrimage Systems." Proceedings, International Seminar: Pilgrimage and Complexity. New Delhi: Indira Gandhi National Centre for the Arts.

Mather, J.R., and S.P. Mather (1997). "DeborahProphetess and Possible Applied Climatologist." Pennsylvania Geographer, 35/2: 32-44.
Morin, K., and J. Kay Guelke (1998). "Strategies of Representation, Relationship, and Resistance: British Women Travelers and Mormon Plural Wives, c 1870-1890." Annals of the Association of American Geographers, 88: 436-462.

Nakagawa, T. (1990). “Louisiana Cemeteries as Cultural Artifacts." Geographical Review of Japan, Series B, 63: 139-155.

Naquin, S., and C.F. Yu (editors) (1992). Pilgrims and Sacred Sites in China. Berkeley: University of California Press.

Newman, W.M., and P. Halvorson (2000). Atlas of Religious Change in America, 1952-1990. 2nd edition. Atlanta, Ga.: Glenmary Research Center.

Nolan, M., and S. Nolan (1992). "Religious Sites as Tourism Attractions in Europe." Annals of Tourism Research, 19: 68-78.

Nolan, M., and S. Nolan (1997). "Regional Variations in Europe's Roman Catholic Pilgrimage Traditions," in Stoddard and Morinis (1997b: 61-93).

Norris, K. (1993). Dakota: A Spiritual Geography. New York: Ticknor \& Fields.

Numrich, P.D. (1997). “Recent Immigrant Religions in a Restructuring Metropolis: New Religious Landscapes in Chicago." Journal of Cultural Geography, 17: 55-76.

O'Brien, J., M. Palmer and D.B. Barrett (editors) (1993). The State of Religion Atlas. New York: Simon \& Schuster. Osterrieth, A. (1997). "Pilgrimage, Travel and Existential Quest," in Stoddard and Morinis (1997b: 25-39).

Pacione, M. (1991). "The Church Urban Fund: A Religio-Geographical Perspective." Area, 23: 101-110.

Pacione, M. (1999). "The Relevance of Religion for a Relevant Geography." Scottish Geographical Journal, 115: $117-131$.

Park, C.C. (1994). Sacred Worlds: An Introduction to Geography and Religion. London: Routledge.

Peet, R. (1998). Modern Geographical Thought. Oxford: Blackwell.

Price, N. (1994). “Tourism and the Bighorn Medicine Wheel: How Multiple Use Does Not Work for Sacred Land Sites," in Carmichael et al. (1994: 259-64).

Prorok, C.V. (1991). "Evolution of the Hindu Temple in Trinidad." Caribbean Geography, 3: 73-93.

Prorok, C.V. (1997). "Becoming a Place of Pilgrimage: An Eliadean Interpretation of the Miracle at Ambridge, Pennsylvania," in Stoddard and Morinis (1997b: 117-39).

Prorok, C.V. (1998). "Dancing in the Fire: Ritually Constructing Hindu Identity in a Malaysian Landscape." Journal of Cultural Geography, 17: 89-114.

Prorok, C.V. (2000). "Boundaries are Made for Crossing: The Feminized Spatiality of Puerto Rican Espiritismo in New York City." Gender Place $\mathcal{E}$ Culture: A Journal of Feminist Geography, 7: 57-80.

Prorok, C.V., and M. Hemmasi (1993). "Muslims and their Mosques in Trinidad: A Geography of Religious Structures and Ethnic Identity." Caribbean $\mathrm{Ge}$ ography, 4: 28-48.

Prorok, C.V., and C.T. Kimber (1997). “The Hindu Gardens of Trinidad: Cultural Continuity and Change in 
a Caribbean Landscape." Pennsylvania Geographer, 35: 98-135.

Pulido, L. (1998). “The Sacredness of 'Mother Earth'; Spirituality, Activism, and Social Justice." Annals of the Association of American Geographers, 88: 719-723.

Raivo, P.J. (1997). “Comparative Religion and Geography: Some Remarks on the Geography of Religion and Religious Geography." Temenos, 33: 137-149.

Reader, I., and T. Walter (editors) (1993). Pilgrimage in Popular Culture. Basingstoke: Macmillan.

Rinschede, G. (1990). “Catholic Pilgrimage Places in the United States," in G. Rinschede and S. M. Bhardwaj (editors), Pilgrimage in the United States. Berlin: Dietrich Reimer, 63-135.

Rinschede, G. (1997). "Pilgrimage Studies at Different Levels," in Stoddard and Morinis (1997b: 95-115).

Rowley, G. (1997). "The Pilgrimage to Mecca and the Centrality of Islam," in Stoddard and Morinis (1997b: 141-59).

Scott, J., and P. Simpson-Housley (editors) (1991). Sacred Places and Profane Spaces: Essays in the Geographics of Judaism, Christianity, and Islam. New York: Greenwood Press.

Sellers, R.W., and T. Walters (1993). "From Custer to Kent State: Heroes, Martyrs and the Evolution of Popular Shrines in the USA," in Reader and Walters (1993: 179-200).

Sherrill, R.A. (1995). "American Sacred Space and the Contest of History," in Chidester and Linenthal 1995: 313-340).

Sheskin, I.M. (1993). "Jewish Metropolitan Homelands." Journal of Cultural Geography, 13: 19-32.

Shilong, Z. (1993). "Ashkenzai Jewish Almshouses in Jerusalem." Journal of Cultural Geography, 14: 5-48.

Shimazuki, H.T. (1997). "The Shikoku Pilgrimage: Essential Characteristics of a Japanese Buddhist Pilgrimage Complex," in Stoddard and Morinis (1997b: 269-297).

Singh, R.P.B. (1991). "Rama's Route after Banishment: A Geographic Viewpoint." Journal of Scientific Research, 41B: 9-46.

Singh, R.P.B. (1994). "The Sacred Geometry of India's Holy City, Varanasi: Kashi as Cosmogram." National Geographical Journal of India, 40: 1-31.

Singh, R.P.B. (1997). "Sacred Space and Pilgrimage in Hindu Society: The Case of Varanasi," in Stoddard and Morinis (1997b: 191-207).

Singh, R.P.B., and J.M. Malville (1995). “Cosmic Order and Cityscape of Varanasi (Kashi): Sun Images and Cultural Astronomy." National Geographical Journal of India, 41: 9-88.

Sinha, A. (1998). "Design of Settlements in the Vaastu Shastras." Journal of Cultural Geography, 17: 27-41.

Smart, N. (editor) (1999). Atlas of the World's Religions. New York: Oxford University Press.

Smith, V.L. (1992). "Introduction: The Quest in Guest." Annals of Tourism Research, 19: 1-17.

Sopher, D. (1967). Geography of Religions. Englewood Cliffs, NJ: Prentice-Hall.

Sopher, D. (1981). "Geography and Religion." Progress in Human Geography, 5: 510-524.

Sopher, D. (1997). “The Goal of Indian Pilgrimage:
Geographical Considerations," in Stoddard and Morinis (1997b: 183-90).

Stoddard, R. H. (1990). "Some Comments about the History of The Geography of Religion and Belief Systems." Geography of Religions E Belief Systems, 12/2: 1-3.

Stoddard R.H. (1994). "Major Pilgrimage Places of the World," in S. M. Bhardwaj, G. Rinschede, and A. Sievers (editors), Pilgrimage in the Old and New World. Berlin: Dietrich Reimer, 17-36.

Stoddard, R.H. (1997). “Defining and Classifying Pilgrimages," in Stoddard and Morinis (1997b: 41-60).

Stoddard, R.H., and A. Morinis (1997a). "Introduction: The Geographic Contributions to Studies of Pilgrimage," in Stoddard and Morinis (1997b: pp. ix-xi).

Stoddard, R.H. (1997b). Sacred Places, Sacred Spaces: The Geography of Pilgrimages. Baton Rouge, La.: Geoscience Publications.

Stump, R.W. (2000). Boundaries of Faith: Geographical Perspectives on Religious Fundamentalism. Lanham, Md.: Rowman \& Littlefield.

Teather, E.K. (1999). "High-Rise Homes for the Ancestors: Cremation in Hong Kong." Geographical Review, 89: 409-430.

Tharan, Z.J. (1997). “The Jewish American Environmental Movement: Stewardship, Renewal and the Greening of Diaspora Politics." Pennsylvania Geographer, 35: 69-97.

Tobin, D.P. (1998). "Moving a Monastery in Modern Times: The Abbey of St. Walburga, Colorado." The Pennsylvania Geographer, 36: 124-134.

Tweed, T. (1997). Our Lady of the Exile: Diasporic Religion at a Cuban Catholic Shrine in Miami. New York: Oxford University Press.

van Spengen, W. (1998). “On the Geographical and Material Contextuality of Tibetan Pilgrimage," in A. McKay (editor), Pilgrimage in Tibet. Richmond: Curzon Press, 35-51.

Voeks, R. (1990). "Sacred Leaves of Brazilian Candomble." Geographical Review, 80: 118-131.

Wagner, P.L. (1997). "Pilgrimage: Culture and Geography," in Stoddard and Morinis (1997b: 299-323).

Webster, G.R. (1997). "Religion and Politics in the American South." Pennsylvania Geographer, 35: 173-202.

Weightman, B.A. (1993). "Changing Religious Landscapes in Los Angeles." Journal of Cultural Geography, 14: 1-20.

Weightman, B.A. (1996). "Sacred Landscapes and the Phenomenon of Light." Geographical Review, 86: 59-71. Wilson, D. (1993). "Connecting Social Process and Space in the Geography of Religion." Area, 25: 75-78.

Yeoh, B.S.A., and T.B. Hui (1995). "The Politics of Space: Changing Discourses on Chinese Burial Grounds in Post-War Singapore." Journal of Historical Geography, 21: 184-201.

Zelinsky, W. (1990). "Nationalistic Pilgrimages in the United States," in G. Rinschede and S. M. Bhardwaj (editors), Pilgrimage in the United States. Berlin: Dietrich Reimer, 253-267.

Zelinsky, W. (1994). Exploring the Beloved Country: Geographic Forays into American Society and Culture. Iowa City: University of Iowa. 